\title{
TECHNOLOGY TRANSFER CONTRACT IN ARAB LEGISLATION
}

\section{ZBIDA ATIM}

Prince Sultan University, Riyadh, Saudi Arabia

Arab countries rely on the development of their industry on engineering technology imported from the major industrial countries. In order to ensure the protection of national companies from the exploitation of international companies owning technology knowledge, it was necessary to identify the legal regime for the transfer of technology in Arab legislation.

We find that the economic openness of Arab countries and the lifting of restrictions on investment The continued growth and spread of technology throughout the world have led to the fall of all barriers.Technology may be tangible in the form of engineering and intangible equipment in the form of knowledge and all related to technological and technological development.
\end{abstract}

KEYWORDS: Contract, Transfer Technology \& Arab Legislation

Received: May 04, 2018; Accepted: May 25, 2018; Published: Jan 07, 2019; Paper Id.: IJPSLIRJUN20194

\section{INTRODUCTION}

The word technology is derived from the Latin language, which consists of two sections techno and is concerned with art or craft and logia, which means study or science. Here, the term technology means scientific applications of science and knowledge in all fields ${ }^{1}$

Technology or technology is an intertextual and interrelated term with more than one definition. One of its definitions is the development and application of tools and the introduction of automated machinery, materials and processes that help to solve human problems resulting from human error. That is the use of tools and capacities available to increase human productivity and improve performance.

Definition of technology: a group of techniques and cognitive skills ${ }^{(1)}$ Engineering industry goes through several stages starting with the design of the commodity and the preparation of drawings and then identify the various components and parts ${ }^{(2)}$

\section{International Legal Regulation for Technology Transfer Contract}

There is no clear definition in national legislation or international law of contracts called "technology transfer contracts there are many forms of technology transfer contracts: the most important of which are foreign direct investment contracts, technology licensing contracts, patents on technical patents and trade relations,

\footnotetext{
${ }^{1}$ https://www.marefa.org

${ }^{(1)}$ D. Faisal Mohammed: The impact of modern scientific renaissance on legal thought Center of Arab Studies for publication and distribution 2015. P. 483

${ }^{2)}$ Dr. Quality Abdel -Khaliq: Industry and Manufacturing in Egypt the reality and the future until 2020 Third World Forum Academic Library: 2005 Egypt p 280
} 
Technical assistance or technical cooperation, organization, training and qualification contracts, and turnkey contracts ${ }^{(3)}$.

In 1975, the United Nations General Assembly decided to refer to the transfer of technology to the Conference on Trade and Development, which established a committee. It established a unified codification of the transfer of technology in 1985, As well as the efforts of the WIPO Organization to produce the Standard Guide to the Legal Aspects of Negotiations and the Preparation of Industrial Property Licenses and Technology Agreements for the Needs of Developing Countries . $\left({ }^{1}\right)$ Where the guide dealt with the transfer of technology, the data of the technology supplier and the preparation of its applications, the participants and the mediators in negotiating the terms of the transfer of technology transactions and determining the necessary licenses and legal documents. In addition to the efforts of UNCITRAL in organizing the transfer of technology through the Model Law on Electronic Commerce of 1996, as follows: "This Act applies to any type of information in the form of a data message used in the context of commercial activities The Commission interpreted the interpretation of the term commercial activities as including: Licenses where is a kind of contract transfer technology.

Contract for the transfer of engineering technology in Arab legislation:There is no special legal regulation for the technology transfer contract in most Arab legislations In many Arab countries, it was organized into unnamed contracts, And linked other Arab countries between technology and investment, These countries have organized technology transfer contracts in foreign investment laws, $\left({ }^{2}\right)$ And that national legislation has been criticized for the inadequacy of organized legal norms. To invest in the capital element with the nature of technology that is not considered a material element, And this is what the Sudanese legislator went to regulate the transfer of technology in the laws of promoting investment Article 7 of the Sudanese Investment Promotion Act $1990^{(1)}$ This law aims to encourage investment in development projects. And is working on the transfer and use of modern technology suitable for Sudan. "However, the transfer of technology contracts from the amended investment laws to the 2013 law was repealed and deleted from its regulation which is understood to be the general rules governing civil contracts in the Civil Transactions Act of 1984 which do not know this type of modern contracts(2). Some Arab legal systems have developed special rules regulating technology transfer contracts, Organized by the Egyptian Commercial Law of 1999 in Articles 172 to 186. and The Jordanian Trade Secrets Protection Act 2000, the Trademarks Trade Secrets and Protection from the Unlawful Competition of Oman Act 2000, Some of the legislation of developing countries are referred to in the area of technology transfer, the term defense legislation, As the aim is to preserve the interests of those countries in the face of international companies $\left({ }^{3}\right)$ And organized by the Saudi legislator in the list of confidential trade information for 2005, . "(4)"The proposal of the unified Arab commercial project in Article 149/1 "The provisions of this Chapter shall apply to the transfer of technology, whether domestic or international nor to the nationality of the parties to the contract or place of residence

\section{First: The Concept of the Contract of Technological Transfer}

Defined by the United Nations Conference on Trade and Development (UNCTAD) as "anything that can be a shop for sale, purchase or exchange in particular technical knowledge and skills that are inseparable from working

\footnotetext{
${ }^{(3)}$ https://www.marefa

${ }^{1}$-Dr. Wafa Mohammedine: The legal framework for the transfer of technology in the light of international efforts - New University House - Alexandria p. 11

2Dr. Salah al - Din Jamal al - Din: contracts transfer of technology University Thought House 2004 p11

$\left({ }^{1)}\right.$ Modified on March 4, 2013

(2)Sudanese civil transactions law issued on 14 - 1984

(3)Dr. Jalal Wafaa Mohammedin: A previous reference. P. 11.

(4)Consolidated Arab Commercial Project Articles 149 to 164
} 
persons $^{(1)}$ "In Arabic jurisprudence, it is defined as the sum of technical knowledge necessary for the optimal use of an industrial method or the installation or exploitation of a particular device ${ }^{(2)}$

Article 2 of the Dubai Free Zone for Technology and InformationLaw2006Technology:All fields of computer, data, and video recording, communication services and the transmission of information using technical means, computer equipment, computers, software and communication networks of all kinds ${ }^{(3)}$

It is defined in Article 73 of the Egyptian Commercial Law of 1999, which corresponds to Article 150 of the Consolidated Arab Commercial Plan "as an agreement under which the technology supplier can transfer technical information to the technology importer for use in a special technical way to produce, develop, To provide services."

In accordance with Article 9 of the Jordanian Unfair Competition and Trade Secrets Law: Any provision or condition contained in a license contract relating to any intellectual property rights may be considered to have a negative impact on trade and may hinder the transfer and dissemination of technology: ${ }^{(1)}$

- The licensee is obliged not to transfer the improvements he makes to the technology covered by the license contract except for the licensee

- The licensee shall not prevent the administrative or judicial dispute in the right of ownership of the idea that has been licensed

- $\quad$ Requiring the licensee to accept the license a set of rights instead of one right.

It is clear that the technology contract is related to the technical and technical knowledge and information and training of the employees of engineers and technicians in the field of technology and technical assistance. From the previous definition, certain conditions must be met in the transfer contract of technology:

- The contract must be in writing or otherwise void.

- Completion of the contract for all data related to the elements of technical knowledge to be transferred $\left({ }^{2}\right)$

- The contract does not include a condition that restricts the freedom of the importer of technology,

where the supplier may impose restrictive conditions on technology, and these arbitrary conditions may hinder the contract transfer of technology and examples of these conditions. ${ }^{(1)}$ :

- Restrict the licensee's freedom to conduct research and development or make improvements or modifications to the product

- Put quantitative restrictions on the volume of production or distribution areas with a view to raising prices.

- Obligating the recipient of the technology to pay the amount or performance of obligations in return for the continued use of industrial property rights and provided for in Article 75 of the Egyptian Commercial Law of

\footnotetext{
${ }^{(1)}$ Dr. Hossam El-Din El-Saghir: Intellectual Property Licensing and Technology Transfer. The National Seminar on Intellectual Property Sultanate of Oman Muscat, March 23, 2001

${ }^{(2)}$ Dr. Ahmed Mohamed Mehrez: Commercial Contracts and Bankruptcy - Dar Al-Nahda Al Arabiya - Cairo - 2001 P.15

${ }^{(3)}$ Dubai Free Zone Law for Technology and Information No. 1 of 2006

${ }^{(1)}$ Law No. 15 of the year 2000

(1)- ${ }^{2}$ Dr.. Mounir Mohammed Al - Janabihi: Mamdouh Al - Janabi: commercial contracts Dar Al - Fikr Al - Jami 'Alexandria 2000 p 12

(2)Dr.. Hossam al-Din al-Saghir: a previous reference p.12
} 
1999.

"Any condition set forth in the contract of transfer of technology may be nullified and may restrict the freedom of the importer to use, develop, This applies in particular to the conditions for which the importer's obligation is ordered by the following:

- $\quad$ Accept vendor improvements to technology and value performance.

- Prohibition of improvements or modifications to the technology to suit the local conditions or the circumstances of the origin of the importer, as well as the prohibition of access to other similar technology or competition to the technology in place of the contract.

- Use of certain brands to distinguish goods that used technology in their production

- Restricting the volume or price of the production or how it is distributed or exported.

- The participation of the supplier in the management of the importer's establishment or its interference in the selection of its permanent employees.

- The purchase of raw materials, metals, machines, equipment or spare parts for the operation of technology from the supplier alone or from the establishment which he or she owns.

- In order to sell the production or the power of attorney to sell it to the supplier or persons he appoints.

\section{Forms of Technology Transfer Contracts}

Can be divided according to the nature of the work carried out by the supplier of technology and allows the importer to use them according to the terms of the contract. These contracts vary from the industrial license contract, the transfer of technical knowledge and the knowledge assistance contract. The contract includes engineering services, patents, industrial licensing, and turnkey contracts. It is a contract of netting that is not replaced by a specific inventory. Or transfer knowledge in various forms as feasibility studies. ${ }^{(1)}$.

Second: Mutual obligations in the technology transfer contract This contract, like other commercial contracts, has obligations on both parties, and most of these obligations fall on the supplier of technology.

\section{Supplier Obligations}

- The supplier shall provide the importer with the information, data and other technical documents necessary for the operation of the technology.

- The supplier is obliged to provide the importer upon request the spare parts produced and needed by the machines or equipment used in the operation of the technology at their market price, with the knowledge of the sources of their acquisition, if the supplier does not produce these pieces in the facility. $\left({ }^{2}\right)$

\section{Obligations of the Importer :Its Obligations are Limited to}

- $\quad$ pay the corresponding technology.

\footnotetext{
${ }^{(1)}$ Dr.SumayaElkalyouby 2008 http://www.bibliotdroit.com

${ }^{2}$ Article 78 of the Egyptian Commercial Law of 1999
} 
- commitment not to go down to others.

- Maintain the confidentiality of technology

In the event of disclosure of information on technology, the importer shall be compensated in accordance with Article 34 of the Omani Unfair Competition and Trade Secrets Act of 2002, which states that "natural and legal persons are prohibited from disclosing trade secrets in their possession in a manner contrary to the fair practice of trade"The importer must maintain the confidentiality of the technology obtained and the confidentiality of the improvements to which it is applied

Applicable Law on Technology Transfer Contract; The jurisprudence of private international law has settled the contract of transfer of technology to the law of will Jurisprudence excludes two aspects of the scope of application of this law, namely the form of contract and the eligibility of contractors where the form of the contract is subject to the law of the State where the contract is concluded The civil status officer for a nationality is home or nationality ${ }^{(1)}$ The problem of applicable law is not already raised in the sphere of domestic trade contracts, which are subject to the domestic law of the contractors in advance of the legal regime on which they were contracted there may be conflict in technology transfer contracts because of its association with more than one person and one legal system, which requires determining the law applicable to the contract The origin of the contracts of international technology is subject to the law of will, ie the law indicated by the will of the contractors. The law will apply to everything related to the formation of the contract and the substantive conditions. The law also applies to the effects of the contract whether these effects are related to persons or subject matter and to all the obligations that the contract entails between its parties and the penalty for violating these obligations $\left({ }^{1}\right)$

And the application of the law of will recognized in Arab legislation "The contract of the law of the contracting parties may not be revoked or amended except by agreement of the parties or for the reasons determined by law." The authorities of the administration begin a consistent principle in comparative law, which is recognized by all legal systems $\left({ }^{2}\right)$ The concept of the law of will: The law of will or powers of will means that will is the source of personal rights as the special instrument of law, which results in the field of internal law several principles representing the principle of freedom of contract and respect the will of the contractors in the interpretation and implementation of the contract. Article 3 (1) of the 1980 Rome Convention on the law applicable to contractual obligations stipulates that "the contract shall be the law chosen by the parties. This choice shall be explicit or derived in a certain manner from the provisions of the contract or the conditions of the contract."

Settlement of Disputes of Technology Transfer Contracts by Arbitration: The UNCITRAL Model Law on International Commercial Arbitration defined the arbitration agreement in article 7 of which stipulates that "an agreement between the parties to refer to arbitration all or some specific disputes that have arisen or may arise between a specific legal relationship, contractual or non-contractual, The arbitration agreement shall be in the form of an arbitration clause contained in a contract or in the form of a separate agreement). It is an agreement by which the parties choose and are willing to refer the disputes that arise between them to a third party to resolve the dispute by binding

1)

Dr. Mahmoud Mohamed Yaqout: Freedom of the Oppressed in the Selection of the Law of the International Decade: Establishment of Alexandria 2004 - p. 19

$\left({ }^{1}\right)$ Dr.HishamAliSadiq Law applicable to international trade contracts - University Thought - Alexandria - 2001 p.17 .

${ }^{2}$ Lazar bin Said Legal System for the Decade of Electronic Commerce - Dar Al-Fikr - Alexandria -2009 p. 167. 
In accordance with the UNCITRAL Law, the Arab legislations issued laws for commercial arbitration, including the arbitration system in the Kingdom of Saudi Arabia for the year B and the Egyptian arbitration law for the year 1994, the Jordanian in 2001, the Bahraini in 1994, the Tunisian in 1993, the Egyptian in 1990 and the Lebanese in 1993

Applicable Law in the Arbitration of Technology Transfer Contract Disputes :International arbitrators in Arab legislation do not have a law of internal jurisdiction, and the international commercial arbitration courts resort to the rules of private international law in general or to the principles that have been established in international arbitration based on the model contracts of Fidek, (1)This is explained in Article 25 of the Saudi Arbitration Law "The two parties to arbitration have the right to agree on the procedures followed by the arbitral tribunal, including their right to subject these procedures to the rules in force in any organization, body or arbitration center in the Kingdom or abroad, provided that they do not violate the provisions of Islamic law ${ }^{(1) "}$ And Article (30) of the Sudanese Arbitration Law No (1)of 2005, corresponding to article 39/1 of the Egyptian Arbitration Law, which provides that "the arbitral tribunal shall apply the rules agreed upon by the parties to the subject matter of the dispute and if they agree to apply the law of a particular State, The substantive rules were followed unless otherwise agreed "and those national legal systems were in agreement with.This is what was stated in article 28 of the, UNCITRAL Law, which states: The arbitral tribunal shall decide on the dispute in accordance with the rules of law chosen by the parties as its duty to apply to the subject matter of the dispute and any choice of the law or legal system of a State shall be taken as a direct reference to the substantive law of that State and not to its own rules that. If the parties do not specify any rules, the arbitral tribunal must apply the law determined by the rules of conflict of laws which the arbitral tribunal considers to be applicable ". It is clear from the foregoing that the parties to the arbitration agreement are free and broad in determining the law applicable to the subject matter of the dispute and choosing the procedures followed. In this regard, the New York Convention signed in 1958 provided an indirect conflict rule in Article 15.1.5: "The recognition and execution of the judgment upon the request of the opponent against whom the judgment is made shall be made only if it is submitted to the competent authority of the country required to recognize and enforce the formation of the arbitral tribunal in contravention of the agreement of the parties or contrary to the law of the country where the arbitration was made in case of disagreement.

\section{A Form of Arbitration in Technology Transfer Contracts}

Under the UNCITRAL Model Law on International Commercial Arbitration of 1994, the arbitration agreement is written in Article 7/2 of which "the arbitration agreement must be in writing and the agreement shall be in writing if it is contained in a document signed by the parties or in the exchange of letters, correspondence, Other wireless means of communication shall serve as a record of agreement or in the exchange of data" As for the Arab legislations regarding the arbitration agreement, most countries require their legislation is written and documented agreement, including sometimes only verbal agreement This is stated in Article (9) of the Saudi Arbitration Law, which stipulates that writing in the arbitration agreement "The arbitration agreement must be in writing or the invalidity of arbitration Such as the Sudanese law of arbitration. Article (8) of the Sudanese Arbitration Law of 2005, which corresponds to Article 12 of the Egyptian Arbitration Law, stipulates that "the arbitration agreement must be written or otherwise null and void."

The extent of recognition of the binding power of the arbitral tribunal's decisions to transfer the technology : International conventions have given Arab legislations the same arbitral awards as the judgments issued by the judiciary.$\left({ }^{1}\right)$

\footnotetext{
${ }^{(1)}$ Royal Decree No. 46 of 1403

$-{ }^{1}$ Dr. Lazar bin Said: a previous reference p. 232.
} 
Article 3 of the New York Convention states: "Each Contracting State shall recognize the decisions of arbitration as binding decisions Article 35 of the UNCITRAL Model Law on International Commercial Arbitration states that "Decisions by an arbitral tribunal are binding irrespective of the country in which they were issued" This is what the Sudanese legislator referred to in article (40) of the Sudanese Arbitration Law of 2005, which states: "The decision of the arbitral tribunal shall be binding and executed automatically or upon written request to the competent court, accompanied by a certified copy of the original decision. Way of invalidity "Article (55) of the Egyptian Commercial Arbitration Law provides that "the arbitrators' judgments issued in accordance with this law shall have the authority of the order and shall be enforceable subject to the provisions provided for in this law."

\section{CONCLUSIONS}

The study dealt with the transfer of engineering technology in Arab legislations, showing the concept of transfer of technology and the obligations of the parties and arbitration as a mechanism for settling disputes of contracts of technology transfer. The most important results were as follows:

- Arab reference are low due to the lack of clear Arab legislation regulating the transfer of technology in all its forms

- The contract of transfer of technology from the legal economic contracts, but the Arab legislation did not settle on a definition or concept, despite its importance in organizing the transfer of technology and the protection of the local importer of technology explicitly except for Egyptian law 1999

- Technology transfer is subject to the rule of will

- The law applicable in the settlement of Disputes of the Technology Transfer Contract The Arbitration Law, where Arab legislation has established clear rules of arbitration consistent with international conventions

\section{RECOMMENDATIONS}

- Legislation of Arab laws regulating the rules of technology transfer contract in accordance with international trade rules

- Preparing international and regional workshops and seminars to demonstrate the importance of this type of contract

\section{REFERENCES}

1. Jalal Wafaa Mohammedin: the legal framework for technological transfer in light of international efforts - New University House - Alexandria

2. Hisham Ali Sadiq Law applicable to international trade contracts - University Thought - Alexandria - 2001

3. Munir Mohammed Al-Janabihi: Mamdouh Al-Janabihi: Commercial Contracts Dar Al-Fikr University Alexandria 2000

4. Adeke Aondongu Abel Esq, An Appraisal of the Legal Framework for Mergers and Acquisitions in Nigeria, International Journal of Accounting and Financial Management Research (IJAFMR), 7(5), 23-36

5. Salah al-Din Gamal al-Din: contracts transfer of technology Dar al-Fikr University in 2004

6. Hossam El-Din El-Saghir: Intellectual Property Licenses and Technology Transfer. The National Seminar on Intellectual 
Property Sultanate of Oman Muscat 24 March 2004

7. Lazar bin Said Legal System for the Decade of Electronic Commerce - Dar Al-Fikr - Alexandria -2009

8. Faisal Mohammed: The impact of modern scientific renaissance on legal thought Center of Arab Studies for publication and distribution 2015.

9. UNCITRAL Model Law on International Commercial Arbitration

10. New York Convention on Arbitration 1958 